\title{
Purification and antigenic characteristics of a rickettsia-like organism from the oyster Crassostrea ariakensis
}

\author{
Xinzhong Wu ${ }^{1,2, *, * *}$, Jingfeng Sun ${ }^{2, * *}$, Weizhu Zhang' ${ }^{2}$, Bohai Wen ${ }^{3}$ \\ ${ }^{1}$ College of Animal Sciences, Zhejiang University, 268 Kaixuan Road, Hangzhou 310029, China \\ ${ }^{2}$ The South China Sea Institute of Oceanology, The Chinese Academy of Sciences, 164 West Xingang Road, \\ Guangzhou 510301, China \\ ${ }^{3}$ Institute of Microbiology and Epidemiology, Beijing 100071, China
}

\begin{abstract}
A rickettsia-like organism (RLO) has been suggested to be the etiological agent responsible for heavy losses of the oyster Crassostrea ariakensis Gould in China. Because of the lack of molluscan cell lines for in vitro culture of intracellular prokaryotes, antigenic analysis of RLOs has been limited by the inherent difficulties of their purification. In this report, we describe the use of differential speed centrifugation and renografin density gradient centrifugation to purify the RLO directly from infected oyster tissues. The purity and integrity of purified prokaryotes were validated by transmission electron microscopy. Thirteen major constituent proteins, with molecular weights ranging between 17 and $99 \mathrm{kDa}$, were electrophoretically identified by silver staining, and 8 major proteins were identified with Coomassie blue R staining. Specific mouse polyclonal antiserum was prepared for serological characterization of the RLO and was used in an immunoblot assay, and 3 major antigen groups were identified. The present results advance our knowledge of RLO protein antigens, and several proteins have been identified that could potentially be useful for diagnostic assays or for production of experimental immunostimulants.
\end{abstract}

KEY WORDS: Rickettsia-like organism - Crassostrea ariakensis · Antigenic characteristics · Purification Resale or republication not permitted without written consent of the publisher

\section{INTRODUCTION}

Since the first report of rickettsia-like organisms (RLOs), chlamydia-like organisms (CLOs) and mollicute-like organisms (MLOs) from bivalves (Harshbarger et al. 1977), there have been numerous reports of RLOs, and a few reports of CLOs and MLOs, from marine mollusks (Azevedo 1993, Wu \& Pan 1999a). Most prokaryote infections are associated with mass mortalities and the majority are RLOs. Thus, clinical rickettsioses have been described among many marine mollusks (Gulka et al. 1983, LeGall et al. 1988, Norton et al. 1993, VanBlaricom et al. 1993, Wu \& Pan 1999a,b, Moore et al. 2000, Wu \& Pan 2000). But unlike Rickettsia infecting mammals, few studies have reported on natural routes of transmission or pathogenic mecha- nisms of those infecting aquatic species (Almendras et al. 1997). Most mollusk RLOs are genetically, biochemically and serologically undefined, so the relatedness of geographically or biologically distinct isolates remains unknown. Many unknown rickettsia-like organisms from marine mollusks have only been described by light or electron microscopy; few have been characterized genetically or immunologically (LeGall \& Mialhe 1992, Andree et al. 2000, Friedman et al. 2000). The 16SrDNA of rickettsia-like organisms from 2 different abalone species, Haliotis cracherodii (Andree et al. 2000) and Haliotis spp. (Friedman et al. 2000), have been amplified, cloned and sequenced. In addition, cell proteins of the RLO from the Saint-Jacques scallop Pecten maximus were isolated and characterized electrophoretically by LeGall \& Mialhe (1992). 
Populations of the oysters Crassostrea ariakensis suffered heavy losses during recent winters and springs in China. A potential pathogen, a rickettsialeslike organism, was discovered in the oyster $(\mathrm{Wu} \& \mathrm{Pan}$ 2000, Sun \& Wu 2004). To better understand the significance of these molluscan RLOs in terms of pathogenicity, epidemiological investigation and taxonomy, we should characterize them at the molecular level.

An important step in characterization of RLO proteins is the purification of the organism from infected tissues. Intracellular bacteria are usually incompletely released from cells, and more than half of the total infectious particles may remain associated with intact cells or cell ulcer debris (Moulder 1985). Some protocols have been established for vertebrate Rickettsiales, which can be cultured in the yolk sac of chicken embryos (Dasch \& Weiss 1977, Williams et al. 1981) or grown in tissue culture (Weiss et al. 1975). Several techniques have been used for purifying various Rickettsiales (Tamura et al. 1982), specifically, isopycnic density gradient centrifugation in Percoll or in diatrizoate meglumine and diatrizoate sodium (DMDS, commercially known as renografin or hypaque). A Percoll density gradient centrifugation technique, modified from Tamura et al. (1982), was used by Kuzyk et al. (1996) to purify Piscirickettsia salmonis from cultured cells. Because of the lack of molluscan cell lines for in vitro culture of intracellular prokaryotes, rickettsia-like organisms must be purified from infected marine mollusk tissues. Applying centrifugation techniques, which were successfully used to purify intracellular protozoan the Bonamia ostreae, a parasite affecting the flat oyster Ostrea edulis (Mialhe et al. 1985, 1988), LeGall \& Mialhe (1992) and Li \& Wu (2004) were able to purify RLOs directly from infected tissues of Pecten maximus and Argopecten irradians, respectively.

In our study, RLOs were purified from infected tissues of the oyster Crassostrea ariakensis by renografin density gradient centrifugation, and their cell proteins were electrophoretically characterized for the first time. The availability of highly purified prokaryote suspensions permitted the preparation of specific polyclonal antibodies and the electrophoretic characterization of major proteins that may be related to pathogenicity and immunogenicity of RLOs. Immunoblotting with polyclonal mouse antiserum against RLO from the oyster, $C$. ariakensis was used to identify antigens of RLO.

\section{MATERIALS AND METHODS}

Collection of oysters. Moribund 2 to 3 yr old oysters Crassostrea ariakensis Gould were collected from farms in Hailing Bay in Yangxi County, Guangdong province, China, where oysters have been heavily infected with RLOs in recent years (Sun \& Wu 2004). Healthy 2 yr old oysters $C$. ariakensis were collected from other unaffected culture farms in Leizhou Bay in Guangdong province, China.

Purification protocol. A purification protocol modified from LeGall \& Mialhe (1992) and Li \& Wu (2004) was used to purify the RLO from infected tissues of the oyster. Ten infected oysters were washed with PBS (phosphate-buffered saline, $\mathrm{pH}$ 7.4: $\mathrm{Na}_{2} \mathrm{HPO}_{4}, 53.9 \mathrm{mM}$; $\mathrm{KH}_{2} \mathrm{PO}_{4}, 12.8 \mathrm{mM}$; NaCl, $72.61 \mathrm{mM}$ ). Infected tissues, including mantles, gills and digestive glands from 10 oysters were dissected and suspended in PBS and homogenized with a mechanical homogenizer (Ningbo Kesheng). The homogenates were centrifuged at $11000 \times g$ for $40 \mathrm{~min}$ at $4^{\circ} \mathrm{C}$. Fat adhering to the wall of the tubes and supernatants was removed by aspiration, and the pellets were resuspended in PBS and centrifuged at $700 \times g$ for $20 \mathrm{~min}$ at $4^{\circ} \mathrm{C}$. The supernatant fluids were saved. The pellets were homogenized again, and then the homogenate was centrifuged at $500 \times g$ for $15 \mathrm{~min}$ at $4^{\circ} \mathrm{C}$. The supernatants were saved. The 2 saved supernatants were combined and centrifuged at $11000 \times g$ for $40 \mathrm{~min}$ at $4^{\circ} \mathrm{C}$. The fat and the supernatant were removed by aspiration, the pellets were resuspended in PBS and centrifuged at $500 \times$ $g$ for $15 \mathrm{~min}$ at $4^{\circ} \mathrm{C}$. The pellets were discarded, and the supernatants were saved, layered on a solution of $23 \%$ sucrose $/ 10 \%$ renografin and centrifuged at $25000 \times g$ for $1 \mathrm{~h}$ at $4^{\circ} \mathrm{C}$. The pellets were resuspended in PBS and centrifuged at $11000 \times g$ for $40 \mathrm{~min}$ at $4^{\circ} \mathrm{C}$. Crude RLO pellets were suspended in PBS (1 pellet/ $10 \mathrm{PBS}, \mathrm{w} / \mathrm{v})$. Then, $1.5 \mathrm{ml}$ crude RLO suspension was layered in $10 \mathrm{ml}$ renografin discontinuous gradients $(16 \%, 22 \%, 28 \%, 32 \%$, v/v, each of $2.5 \mathrm{ml}$, prepared by diluting $76 \%$ renografin with $\mathrm{PBS}$ ) in each tube. Six tubes were prepared and then centrifuged at $95000 \times g$ for $40 \mathrm{~min}$ at $4^{\circ} \mathrm{C}$ (Beckman, SW41 Ti). The band of turbidity at the 22 to $28 \%$ interface was collected and diluted slowly 10-fold with PBS and then centrifuged at $25000 \times g$ for $1 \mathrm{~h}$ at $4^{\circ} \mathrm{C}$ to deposit the purified RLO. Parts of RLO pellets were used to make ultrathin sections for transmission electron microscopy (TEM) observation. The others were then suspended in PBS, and then several drops of purified RLO suspension were negatively stained on copper net for TEM observation.

Light and electron microscopy. For light microscopy, infected tissue smears, homogenates or prokaryote suspensions from different purification steps were airdried on glass slides and then fixed in methanol and stained with simple Giemsa staining. For TEM, 2 methods were used: (1) purified RLO pellets were fixed in $2 \%$ glutaraldehyde in a cacodylate buffer system ( $\mathrm{pH} 7.2$ ) and postfixed in $1 \%$ osmium tetroxide in $0.1 \mathrm{M}$ sodium cacodylate buffer $(\mathrm{pH} 7.2)$ for $1.5 \mathrm{~h}$ at 
$4^{\circ} \mathrm{C}$, dehydrated in an ethanol series and embedded in Epon 812 resin; ultrathin sections were cut and stained with uranyl acetate and lead citrate; (2) purified RLO suspensions were negatively stained by putting a drop of RLO suspensions on a copper net covered with formvar, followed by staining with $4 \%$ phosphotungstic acid for 2 min and air-dried. TEM observations were made on a JEOL-100CX electron microscope.

Specific polyclonal antibody preparation. Purified whole cells of RLOs were fixed overnight at $4^{\circ} \mathrm{C}$ in PBS containing $5 \%$ formalin. Freund's complete adjuvant was mixed and emulsified with the RLO supernatant at a ratio of $1: 1$ to obtain a $1 \mu \mathrm{g} \mathrm{ll}^{-1}$ concentration. Mice were immunized with $50 \mu \mathrm{l}$ of the prepared antigens by subcutaneous injection at 4 different sites, respectively; 4 wk later, mice were re-immunized with $100 \mu \mathrm{l}$ of antigens by subperitoneoabdominal injections of the purified prokaryote suspension without Freund's adjuvant. Serum was collected $14 \mathrm{~d}$ after the second injection and clarified by centrifugation at $3000 \times g$ for $15 \mathrm{~min}$ at $4^{\circ} \mathrm{C}$.

Indirect immunofluorecence (IIF). Gill smears of healthy and diseased oysters were air-dried and fixed in acetone for $10 \mathrm{~min}$. They were then overlaid with the immunoserum diluted from $1 / 10$ to $1 / 5000$ in PBS. After a 20 min incubation period inside a moist chamber at room temperature $\left(25^{\circ} \mathrm{C}\right)$, the slides were washed with PBST (phosphate-buffered saline + 0.05\% Tween-20, pH 7.4) buffer and then overlaid with fluorescein isothiocyanate (FITC)-conjugated goat anti-mouse immunoglobulin antiserum (Sihuan SciTechnics) diluted (1/100) in PBS with Evans Blue $(0.01 \%)$. The slides were again incubated inside a moist chamber for $30 \mathrm{~min}$ and washed in PBST buffer 3 times. The slides were examined for the RLO with an epifluorescent microscope. The control antibodies consisted of sera from non-immunized mice.

Electrophoresis. Protein analysis was carried out by sodium dodecyl sulfatepolyacrylamide gel electrophoresis (SDS-PAGE) following the protocol of Laemmli (1970). Purified RLO samples were resuspended in PBS to a concentration of $50 \mu \mathrm{g} \mathrm{ml}^{-1}$ total proteins. The samples were then mixed with SDS buffer that contained $25 \%$ (v/v) $0.5 \mathrm{M}$ Tris-HCl, $20 \%$ (v/v) glycerol, $4 \%$ (w/v) SDS, $2 \%$ (v/v) 2-mercaptoethanol and 0.001\% $(\mathrm{w} / \mathrm{v})$ bromphenol blue. The mixture was heated at $100^{\circ} \mathrm{C}$ for $5 \mathrm{~min}$, then $30 \mu \mathrm{l}$ of each sample was added to an individual well of a $10 \%$ SDS-PAGE gel. Prestained middle-molecular weight standard proteins (Amersham Pharmacia) were added to wells on either side of the experimental samples. The gel electrophoresis was carried out by an electrophoretic apparatus (Hoefer miniVE, Amersham Pharmacia) operating at $100 \mathrm{~V}$ at room temperature $\left(25^{\circ} \mathrm{C}\right)$ until the dye front reached the bottom of the gel. Protein bands were visualized with silver staining and Coomassie brilliant blue R-250 staining. The molecular weight of the denatured protein was tested according to the middlemolecular weight standards (Amersham Pharmacia). The size and relative quantities of individual bands were evaluated with a CS-9000 dual-wavelength flying spot scanner (Shimadzu Corp).

Immunoblotting. The method of Barnes et al. (1998) was partially modified as follows: SDS-PAGE gels were loaded with RLO samples in each lane and the gels run as described. Separated proteins in the unstained gels were electrophoretically transferred onto nitrocellulose membranes using $100 \mathrm{~V}$ for $1 \mathrm{~h}$ at $4{ }^{\circ} \mathrm{C}$. The membranes were shaken in $5 \%(\mathrm{w} / \mathrm{v})$ nonfat dry milk dissolved in $10 \mathrm{mM}$ Tris- $\mathrm{HCl}(\mathrm{pH}$ 8.0) with $150 \mathrm{mM} \mathrm{NaCl}$ (TBS) for $1 \mathrm{~h}$ at room temperature. The membranes were rinsed in TBS with $0.05 \%$ Tween 20 (TBST), immersed in the primary antibody diluted 1:200 in TBST and shaken for $90 \mathrm{~min}$. The secondary antibody was a peroxide-labeled goat anti-mouse serum (Sihuan Sci-Technics) diluted to 1:2000 in TBST. The membranes were rinsed twice in TBST for $20 \mathrm{~min}$ before immersion in the secondary antibody with further shaking for $90 \mathrm{~min}$. The membranes were then rinsed 3 times for $20 \mathrm{~min}$ with TBST and developed with diaminobenzidine and nickel chloride as described in Sambrook et al. (p. 881-898).

\section{RESULTS \\ Examination of purified products and
purification protocol}

The homogenates after different speed centrifugations, examined by light microscopy, contained many intact host nuclei, amorphous material and numerous RLOs. The result of the final centrifugation showed that most soluble material and large particles were essentially eliminated and that the RLOs were concentrated.

During renografin density gradient centrifugation, the RLOs formed a minor band at the 16 to $22 \%$ interface containing primarily host nuclei, and formed a major band at the 22 to $28 \%$ interface containing pure RLOs.

Ultrastructural examination of purified microorganisms via TEM allowed identification of key characteristics, particularly the sizes, cell wall and inner structure of bacterial bodies, which are identical to organisms observed in tissue with TEM (Wu \& Pan 2000, Sun \& Wu 2004), and demonstrated that they were the rickettsialike organisms from the oyster. They had a rather smoother trilaminar cell wall, the outer and the inner layer of which were electron dense, the middle was electron lucent, and the inner was obviously thicker 
than the outer. There was an obvious slime layer on the outer membrane surface. The cytoplasm of the organisms, tightly packed with compact ribosomes, was in a wide area of the periphery. The compact chromatin, a dark dot and filamentous structures, presumably DNA, occurred in the nucleoidal area (Fig. 1). TEM observation of negatively stained sections revealed that the band at the 22 to $28 \%$ interface contained a nearly pure concentration of intact bacteria that was homogeneous in appearance. Most organisms purified were spherical, or occasionally rod shaped, and ranged from approximately 0.32 to $0.6 \mu \mathrm{m}$ in size $(\mathrm{n}=20)$ (Fig. 2).

\section{Indirect immunofluorescence}

The sera of immunized and control mice were tested against tissue smears of healthy and diseased oysters. Specific recognition of prokaryote cells was obtained for the dilution range between $1 / 100$ and $1 / 2000$. The optimal concentration was $1 / 800$ (Fig. 3). No specific fluorescence was observed from healthy oysters.

\section{Electrophoretic pattern}

A total of 13 major proteins were identified by silver staining after SDS-PAGE (Fig. 4). Their molecular weights, estimated by comparison with electrophoretic mobilities of reference mark proteins, ranged between 99 and 17 kDa: P1, 99 kDa; P2, 96 kDa; P3, 82 kDa; P4, 63 kDa; P5, 56 kDa; P6, 44 kDa; P7, 41 kDa; P8, 39 kDa; P9, 34 kDa; P10, 30 kDa; P11, 22 kDa; P12, 19 kDa; and P13, 17 $\mathrm{kDa}$. However, only 8 major proteins the molecular weights of which were $63 \mathrm{kDa}(\mathrm{P} 4) ; 56 \mathrm{kDa}(\mathrm{P} 5) ; 44 \mathrm{kDa}$ (P6); $41 \mathrm{kDa}(\mathrm{P} 7) ; 39 \mathrm{kDa}(\mathrm{P} 8) ; 34 \mathrm{kDa}$ (P9); $30 \mathrm{kDa}(\mathrm{P} 10) ;$ and $17 \mathrm{kDa}$ (P13) were identified with Coomassie blue R-250 staining. The result of the scanning analysis of the cell proteins from silver staining showed percentage as follows: P1, 0.542; P2, 12.135; P3, 2.817; P4, 5.490; P5, 3.084; P6, 17.175; P7, 3.314; P8, 16.394; P9, 4.120; P10, 3.547; P11, 1.202; P12, 5.763; and P13, 24.390.

\section{Immunoblotting}

The immunoblotting result of cell proteins from purified RLOs revealed the presence of 3 antigens of $56 \mathrm{kDa}$ (P5), $44 \mathrm{kDa}(\mathrm{P} 6)$ and $34 \mathrm{kDa}(\mathrm{P9})$ that reacted with mouse anti-RLO serum prepared as above (Fig. 5).

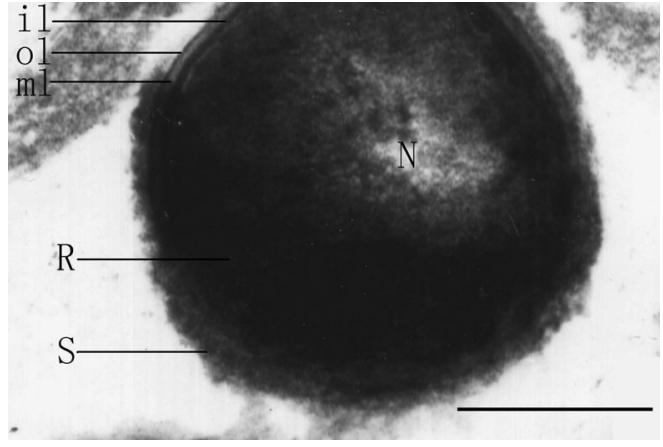

Fig. 1. Ultrathin section of a purified rickettsia-like organism (RLO). The sphere-shaped RLO has a fairly smooth trilaminar cell wall, whose outer (ol) and the inner (il) layers were electron dense while the middle layer (ml) was electron lucent. The inner layer was thicker than the outer. There was a slime layer (S) on the outer membrane surface and many electrondense granular materials as ribosome bodies (R) near the periphery. The compact chromatin, a dark dot and filamentous structures, presumably DNA, occurred in the nucleoidal area $(\mathrm{N})($ scale bar $=0.3 \mu \mathrm{m})$

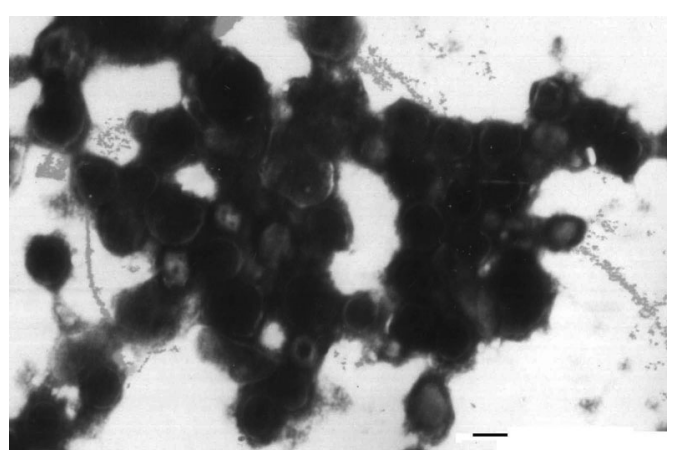

Fig. 2. Section negatively stained with phosphotungstic acid. Purified rickettsia-like organisms from infected oyster tissues observed with TEM (scale bar $=0.3 \mu \mathrm{m})$

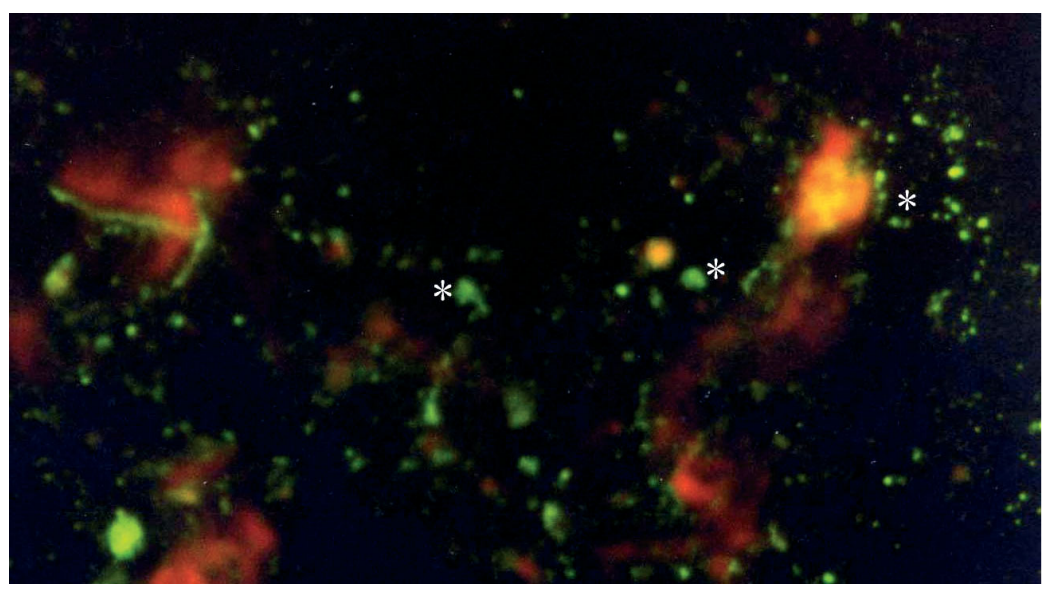

Fig. 3. Indirect immunofluorescence microscopy $(\times 400)$. The primary antibody was mouse anti-RLO serum and the second antibody was goat anti-mouse IgG conjugated to fluorescein isothiocyanate. Specific polyclonal antiserum against RLOs was tested against gill smears of diseased oysters (*, specific fluorescence from the rickettsia-like organisms and their inclusions) 


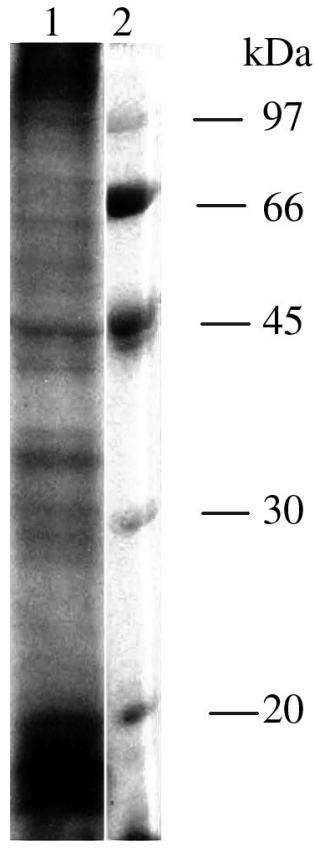

Fig. 4. Electrophoretic pattern of proteins of purified RLOs. Lane 1: gradient-purified RLOs from the oyster were centrifuged and resuspended in distilled water. Lane 2: protein molecular weight marker. Samples mixed with SDS sample buffer were heated to $100^{\circ} \mathrm{C}$ for $5 \mathrm{~min}$, then $30 \mu \mathrm{lsam}-$ ple was loaded into a sample well of a $10 \%$ SDS-PAGE gel. The gel was treated with silver staining

\section{DISCUSSION}

RLOs from the mollusks Placopecten magellanicus (Gulka \& Chang 1984), Pecten maximus (LeGall \& Miachle 1992) and Argopecten irradians (Li \& Wu 2004) have been purified by differential sedimentation and density gradient centrifugation. Furthermore, LeGall \& Miachle (1992) generated specific polyclonal mouse serum against the RLO from P. maximus.

In our study, with phosphotungstic acid (PTA) negative staining, TEM examination demonstrated that the products obtained by the purification protocol were devoid of the host cell debris and mainly composed of materials consistent with the size and morphology of RLOs from the oyster (Sun \& Wu 2004). Furthermore, specific immunofluorescence techniques demonstrated that pure intracellular prokaryotes allowed generation of the specific polyclonal mouse serum. At present, no

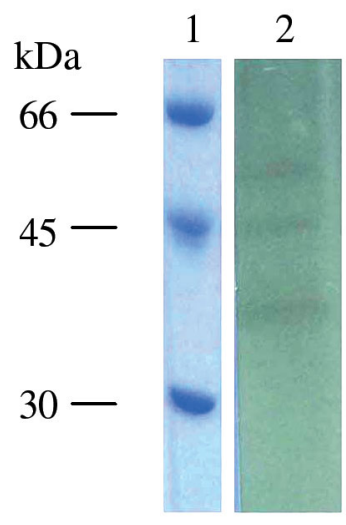

Fig. 5. Western blot analysis of whole-cell proteins of RLOs from the oyster. Lane 1: protein molecular weight marker. Lane 2: whole-cell protein of RLOs were separated by SDSPAGE and reacted with antiRLO mouse serum artificial culture medium or suitable cell lines can reproduce RLOs from marine mollusks, so acquiring purified RLO in this case appears to be much more difficult than from humans or other mammals. The lack of cell lines continues to be a barrier to the study of intracellular pathogens, so it would be very advantageous to be able to isolate RLOs from different marine invertebrate groups, to study pathogenicity, epidemiology, taxonomy, immunology and the molecular biology of RLOs.

LeGall \& Mialhe (1992) established a protein pattern allowing the identification of 15 major proteins with molecular weights of between 148 and $16 \mathrm{kDa}$. In our study, 13 major proteins were identified the molecular weights of which ranged between 17 and $99 \mathrm{kDa}$. Some rickettsial proteins are similar among various species (Barnes et al. 1998). For example, the nucleotide sequence of a $17 \mathrm{kDa}$ protein found in all spotted fever and typhus group rickettsia is highly conserved (Anderson et al. 1990). While some protein molecular sizes of the RLOs from the oyster are similar to those of the RLOs of Pecten maximus (LeGall \& Mialhe 1992) or to those of Ehrlichia (Dumler et al. 1995), molecular size alone is insufficient for comparison. Much work on RLO protein information, including the structure, function and encoded genes, needs to be done.

Additionally, mouse antiserum against purified wholecell RLOs was developed, which permitted indirect immunofluorescence staining techniques specific for the detection of RLOs from oyster.

No previous work has referred to the immunoactivity of the RLO proteins of mollusks. In our study, polyclonal mouse antiserum made against the RLO was also used to identify its antigens. The present work showed that mouse antiserum generated against purified whole-cell RLOs from the oyster Crassostrea ariakensis reacted with 3 predominant antigens: P5 (56 kDa), P6 (44 kDa) and P9 (34 kDa). Many RLO proteins in the present immunoblot tests were denatured by 2-mercaptoethanol and boiling. These results indicated that the 3 predominant antigens reacting with mouse antiserum resist denaturation with 2-mercaptoethanol and boiling. Some heat-labile antigens of Rickettsia rickettsii are strongly antigenic (Anacker et al. 1987, Li et al. 1988, Hackstadt et al. 1992) and may be important stimulators of the host immune response (Schuenke \& Walker 1994). Further studies should be considered to identify a wider range of RLO antigens, including heat-labile proteins in native configurations, glycoproteins, or antigens poorly attached to the surface of the bacterium, except the $56 \mathrm{kDa}, 44 \mathrm{kDa}$ and $34 \mathrm{kDa}$ protein antigens identified in this study. In addition, Piscickettsia salmonis from salmonid fish has been shown to possess protein antigens and carbohydrate antigens that strongly react to rabbit antiserum 
(Kuzyk et al. 1996). The results from this study have increased our knowledge of the protein antigens of RLOs and identified several proteins potentially useful for diagnostic assays or for production of experimental immunostimulants.

Acknowledgements. This study was supported by NSFC (No. 39970581 and No. 30170741), Scientific Program of Zhejiang Province (2004C23041) and Key Science Program (KSCX2SW-302-8) of Chinese Academy of Sciences.

\section{LITERATURE CITED}

Almendras FE, Fuentealba IC, Jones SRM, Markham F, Spangler E (1997) Experimental infection and horizontal transmission of Piscirickettsia salmonis in freshwater-raised Atlantic salmon, Salmo salar L. J Fish Dis 20:409-418

Anacker RL, McDonald GA, List RH, Mann RE (1987) Neutralizing activity of monoclonal antibodies to heat-sensitive and heat-resist epitopes of Rickettsia rickettsia surface proteins. Infect Immun 55:825-827

Anderson BE, McDonald GA, Jones DC, Regnery RL (1990) A protective protein antigen of Rickettsia rickettsii has tandemly repeated, near-identical sequences. Infect Immun 58:2760-2769

Andree KB, Friedman CS, Moore JD, Hedrick RP (2000) A polymerase chain reaction assay for the detection of genomic DNA of a Rickettsiales-like prokaryote associated with withering syndrome in California abalone. J Shellfish Res 19:213-218

Azevedo C (1993) Occurrence of an unusual branchial mycoplasma-like infection in cockle Cerastoderma edule (Mollusca, Bivalvia). Dis Aquat Org 16:55-59

Barnes MN, Landolt ML, Powell DB, Winton JR (1998) Purification of Piscirickettsia salmonis and partial characterization of antigens. Dis Aquat Org 33:33-41

Dasch GA, Weiss E (1977) Characterization of the Madrid E strain of Rickettsia prowazekii purified by renografin density gradient centrifugation. Infect Immun 15:280-286

Dumler JS, Asanovich KM, Bakken JS, Richter P, Kimsey R, Madigan JE (1995) Serologic cross-reactions among Ehrlichia equi, Ehrlichia phagocytophila, and human granulocytic Ehrlichia. J Clin Microbiol 33:1098-1103

Friedman CS, Andree KB, Beauchamp KA, Moore JD, Robbins TT, Shields JD, Hedrick RP (2000) 'Candidatus Xenohaliotis californiensis' a newly described pathogen of abalone, Haliotis spp., along the west coast of North America. Int J Syst Evol Microbiol 50:847-855

Gulka G, Chang PW (1984) Pathogenicity and infectivity of a rickettsia-like organism in the sea scallop, Placopecten magellanicus. J Fish Dis 8:309-318

Gulka G, Chang PW, Marti KA (1983) Prokaryotic infection associated with a mass mortality of the sea scallop, Placopecten magellanicus. J Fish Dis 6:355-364

Hackstadt T, Messer R, Cieplak W, Peacock MG (1992) Evidence for proteolytic cleavage of the 120-kilodalton outer membrane protein of rickettsiae: identification of an avirulent mutant deficient in processing. Infect Immun 60:159-165

Harshbarger HC, Chang SC, Otto SV (1977) Chlamydiae (with phages), mycoplasmas, and rickettsiae in Chesapeake Bay bivalves. Science 196:666-668

Laemmli UK (1970) Cleavage of structural proteins during the assembly of the head of bacteriophage T4. Nature 227: $680-685$

LeGall G, Mialhe E (1992) Purification of rickettsial-like organ- isms associated with Pecten maximus (Mollusca, Bivalvia) serological and biochemical-characterization. Dis Aquat Org 12:215-220

LeGall G, Chagot D, Mialhe EE, Grizel H (1988) Branchial rickettsiales-like infection associated with a mass mortality of sea scallop, Pecten maximus. Dis Aquat Org 4:229-232

Li DF, Wu XZ (2004) Purification and biological features of rickettsia-like prokaryote from the scallop Argopecten irradians in China. Aquaculture 234:29-40

Li H, Lenz B, Walker DH (1988) Protective monoclonal antibody recognize heat-liable epitopes on surface protein of spotted fever group rickettsiae. Infect Immun 56:2587-2593

Kuzyk MA, Thorton JC, Kay WW (1996) Antigenic characterization of the salmonid pathogen Piscirickettsia salmonis. Infect Immun 64:5205-5210

Mialhe E, Bachere E, Le Bec C, Grizel H (1985) Isolation and purification of Marteilia (Protozoa: Ascetospora) parasites of marine Bivalvia: ultrastructural study of pansporoblasts. CR Hebd Seances Acad Sci (III) 301:137-142

Mialhe E, Bachere E, Chagot D, Grizel H (1988) Isolation and purification of the protozoan Bonamia ostreae, a parasite affecting the flat oyster Ostrea edulis L. Aquaculture 71: 293-299

Moore JD, Robbins TT, Friedman CS (2000) Withering syndrome in farmed red abalone Haliotis rufescens: thermal induction and association with a gastrointestinal rickettsialike prokaryote. J Aquat Anim Health 12:26-34

Moulder JW (1985) Comparative biology of intracellular parasitism. Microbiol Rev 49:298-337

Norton JH, Shepherd MA, Abdon-Nagutt MR, Lindsay S (1993) Mortalities in the giant clam Hippopus hippopus associated with rickettsiales-like organisms. J Invertebr Pathol 62: 207-209

Sambrook J, Fritsch EF, Maniatis T (1992) Molecular cloning: a laboratory manual (2nd edn). Science Press, Beijing (in Chinese, translated by D Jin and M Li)

Schuenke KW, Walker DH (1994) Cloning, sequencing, and expression of the gene coding for an antigenic 120-kilodalton protein of Rickettsia conorii. Infect Immun 62:904-909

Sun JF, Wu XZ (2004) The histology, ultrastructure, and morphogenesis of a rickettsia-like organism causing diseases in the oyster Crassostrea arikensis Gould. J Invertebr Pathol 86(3):77-86

Tamura A, Urakami H, Tsurubara T (1982) Purification of Rickettsia tsutsugamushi by Percoll density gradient centrifugation. Microbiol Immunol 26:321-323

VanBlaricom GR, Ruediger JL, Friedman CS, Woodard DD, Hedrick RP (1993) Discovery of withering syndrome among black abalone Haliotis cracherodii Leach, 1814, populations at San Nicolas Island, California. J Shellfish Res 12:185-188

Weiss E, Coolbaugh JC, Williams JC (1975) Separation of viable Rickettsia typhi from yolk sac and L cell host components by renografin density gradient centrifugation. Appl Microbiol 30:456-463

Williams JC, Peacock MG, McCaul TF (1981) Immunological characterization of Coxiella burnetii, phases Iand II , separated from host components. Infect Immun 32:840-851

Wu XZ, Pan JP (1999a) Studies on rickettsia-like organism disease of the tropical marine pearl oyster I: the fine structure and morphogenesis of Pinctada maxima pathogen rickettsia-like organism. J Invertebr Pathol 73:162-172

Wu XZ, Pan JP (1999b) Studies on rickettsia-like organism (RLO) diseases of tropical pearl oyster. IV. On histocytopathology of RLO disease. Acta Oceanol Sin 21(2): 93-98

Wu XZ, Pan JP (2000) An intracellular prokaryotic microorganism associated with lesions in the oyster Crassostrea ariakensis Gould. J Fish Dis 23:409-414 